\title{
Features of consumer value management of an innovative product
}

\author{
Oksana Gaifutdinova*, Igor Poroshin, Elena Sergeeva, and Ekaterina Artemova
}

National Research Polytechnic University, 29a, Komsomolsky prospect, Perm, 614990, Russia

\begin{abstract}
Today, much is being done in Russia to ensure that the country acquires the status of an innovation-oriented power that can occupy and maintain the world leading positions in the main, strategically important areas of the state's development. Successful development of any socio-economic entity operating in modern conditions is impossible without widespread usage of innovative technologies. New technologies are important in open innovation processes for enterprises, because due to them, they can meet customer expectations and achieve higher corporate financial performance. By creating new organizational connections to take advantage of emerging technological opportunities, entrepreneurs are restructuring the economy, driving change and overall economic growth. In addition to the focus on innovation, an important direction in the development concept of a socio-economic entity is solving environmental issues. More and more companies are thinking about creating environmentally friendly products with minimal impact on the environment. Such products have a higher attractiveness for the consumer and compete more successfully with foreign analogues. Creating an effective program of innovative growth in compliance with environmental requirements and standards is one of the most important factors in improving competitiveness and sustainable development of Russian enterprises.
\end{abstract}

\section{Introduction}

Cost management is essential to the success of any enterprise, because one of the most important goals of any company is to maximize its profits. In addition, an important goal of the enterprise is its own survival, and to this extent it seeks to minimize costs, therefore, the goal of good management is efficient usage of resources to maximize profits and maintain the enterprise competitive position. Successful combination of these two goals is achieved through innovation.

In general, innovation is a key factor that increasingly affects economic growth in all countries: these factors can be defined as particularly important circumstances of socio-economic development, as well as technological progress in countries and regions, in enterprises. The process of innovative development is becoming increasingly complex. Many new concepts and types of innovation have emerged, ranging from technological innovation to marketing innovation, and from closed to open innovation [1].

Eco-innovations that take into account modern business models, promising areas of business activity, improving products, as well as environmental and economic processes are becoming particularly popular.

Cost management includes all actions taken by management to reduce costs, without reducing efficiency or affecting customer satisfaction. Competent cost management requires qualitative assessment of the cost drivers in order to be able to successfully control and manage costs [2].
Cost management issues are particularly relevant for innovative products, as they are associated with a large number of additional costs and commercial risks [3]. This process relies on complex networks of partners and external stakeholders interacting through open innovation systems with inbound and outbound practices to address issues related to eco-innovation [4-7].

Implementation of production processes for producing innovative products requires a lot of economic resources. Volumes, types and conditions of their consumption are determined by the specifics of technological processes, implementation of which ensures production of goods with certain consumer characteristics. An important characteristic is the product price, which is determined by the volume of two main components-cost and profit. The value of the production cost depends on the physical and price characteristics of the resources used, determined by the activity of production processes. If the amount of profit is formed mainly under the influence of market conditions for the sale of manufactured products and, therefore, is less sensitive to managerial influences on the part of the enterprise, then the value of the production cost is the object of direct influence, which is sensitive to economic decisions taken at enterprises in relation to the choice of suppliers, the amount of necessary resources and production. Thus, the volume of resources used as well as the economic and organizational conditions for their consumption are of paramount importance for ensuring effective operation of the enterprise [8].

\footnotetext{
* Corresponding author: ogrigoryan@mail.ru
} 
Another key area of developing modern economy and business is active creation of cluster structures of various types. Special emphasis is placed on clusters due to the fact that clusters can play the role of intermediaries for open innovations. There is a two-way relationship: open innovations of companies can determine creativity and complexity of a cluster, while at the same time, openness and creativity of a cluster determine the degree of open innovation of its members. This function is most fully performed by technoparks, which are a special kind of clusters and connect participants in various industries and sectors of the economy [9-12].

Clusters create a favorable environment for open innovations; therefore, cooperation within clusters helps to find sources of innovative development outside the enterprise, for example, by finding and combining ideas that complement existing $\mathrm{R} \& \mathrm{D}$ projects, and creating cooperative relationships with other enterprises and organizations [13]. At the same time, they regulate relations on transferring intellectual property in a certain way [14].

\section{Methods}

A cluster approach is used as a theoretical basis of the study. Clusters are recognized as an important factor of sustainable development because they can influence strategic goals of businesses and scientific units linked in clusters by common research or industrial goals, create social and relational capital based on trust, and stimulate innovation, including eco-innovation and technology.

The research methods are the calculation and analytical method, complex and factor analysis. The method of comparative analysis of efficiency of two operational variants of a gas turbine unit (GTU) for gas superchargers of main gas pipelines with capacity from 4 to $34 \mathrm{MW}$ was also used.

As the study basis, data on the total costs of JSC "UEC-Aviadvigatel" - the design bureau for developing aviation gas turbine engines, as well as industrial gas turbine installations and power plants based on aviation technologies were used [15]. This company is a major manufacturer, as well as a main supplier of parts and components for operational maintenance of a gas turbine unit (GTU) for gas superchargers of main gas pipelines with capacity of 4 to $34 \mathrm{MW}$.

For the analysis, data were taken on the total costs for the GTU operation over the entire life cycle (30 years). The cost data is taken in current prices. The data is presented in table 1 .

Table 1. Costs for the entire GTU life cycle, thousand rubles.

\begin{tabular}{|c|c|c|}
\hline \multicolumn{2}{|c|}{ Costs for GTU Total } & \multirow{2}{*}{ Total } \\
\cline { 1 - 2 } $\begin{array}{c}\text { Capital (for } \\
\text { reconstruction) }\end{array}$ & Operational & \\
\hline 367407,69 & 3705958,76 & 4073366,45 \\
\hline
\end{tabular}

Table 1 shows that the GTU costs consist of capital and operational costs. Their total cost over 30 years is 4,073,366. 45 thousand rubles, of which 367,407. 69 thousand rubles go to capital expenditures and $3,705,958$. 76 thousand rubles for operational costs.

The structure of GTU costs is shown in Figure 1.

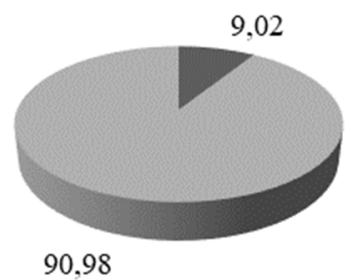

\section{- fixed assets for reconstruction operational cost}

Figure 1. The structure of GTU costs, \%

Figure 1 shows that operating costs account for the largest share of total costs $(90.98 \%)$, while capital costs account for the smallest share $(9.02 \%)$. Thus, the main emphasis in reducing the operating costs of the analyzed equipment should be made on those elements (nodes, parts) of the equipment that require the most attention and the most maintenance costs during the equipment operation. The following calculations are aimed at testing this hypothesis.

\section{Results and Discussion}

In the process of analyzing the studied enterprise capabilities to improve the efficiency of the resources used, as one of the ways to reduce the GTU capital and operating costs, the option of replacing the serial combustion chamber with a low-emission combustion chamber (LECC) was analyzed [16].

The low-emission combustion chamber (LECC) is an innovative product created in the process of scientific and technological cooperation of JSC "UECAviadvigatel" specialists with foreign partners. Thus, JSC "UEC-Aviadvigatel" signed a contract with RGI (USA) for developing LECC for the GTE-25PA. Such cooperation is in the nature of cluster interaction, when experience and resources are shared on mutually beneficial terms [17]. As the basic design, a remote CC with a multi-module front device, previously tested in Aviadvigatel, was selected.

Creation of a low-emission combustion chamber (LECC) is one of the most important tasks facing Perm specialists, since LECC allows achieving a number of important environmental indicators. The use of LECC in modern gas turbine plants reduces the combustion temperature without using water, reduces emission of harmful substances into the atmosphere, which can significantly improve the characteristics of using gas turbine plants, including in the environmental sphere.

Thus, using LECC will ensure that Russian gas turbine equipment complies with the established Russian standards for emissions of nitrogen oxides (NOx) into the atmosphere: no more than $150 \mathrm{mg} / \mathrm{nm} 3$ for gas 
turbine gas transmittal units and no more than 50 $\mathrm{mg} / \mathrm{nm} 3$ for power plants.

Calculation of the total costs for the GTU operation after the LECC introduction showed that during the entire 30-year operational period, these costs will amount to $3,745,454$. 17 thousand rubles. The costs distribution by type (capital and operational) after the LECC introduction during the entire life cycle of GTU is presented in Table 2.

Table 2. Costs for the entire life cycle of GTU with LECC, thousand rubles.

\begin{tabular}{|c|c|c|}
\hline \multicolumn{2}{|c|}{ GTU costs with LECC } & \multirow{2}{*}{ Total } \\
\cline { 1 - 2 } $\begin{array}{c}\text { Capital (for } \\
\text { reconstruction) }\end{array}$ & $\begin{array}{c}\text { Operational } \\
\text { requirements }\end{array}$ & \\
\hline 239391,86 & 3506062,31 & 3745454,17 \\
\hline
\end{tabular}

Table 2 shows that when using LECC, the GTU total cost costs will decrease and amount to 3,745,454. 17 thousand rubles. This reduction will occur both at the expense of part of the capital costs (about 35\%) and at the expense of operating costs (about 6\%). After the events, capital expenditures will amount to 239,391. 86 thousand rubles, and in turn, operating costs - 3,506,062. 31 thousand rubles. The absolute and relative changes in the GTU costs after introducing the LECC are presented, respectively, in Tables 3 and 4.

Table 3. Absolute change in the GTU costs after LECC introduction, thousand rubles.

\begin{tabular}{|l|l|l|l|}
\hline Costs & GTU & $\begin{array}{l}\text { GTU with } \\
\text { LECC }\end{array}$ & $\begin{array}{l}\text { Absolute } \\
\text { deviation }\end{array}$ \\
\hline $\begin{array}{l}\text { Capital } \\
\text { costs }\end{array}$ & 367407,69 & 239391,86 & $-128015,83$ \\
\hline $\begin{array}{l}\text { Operation } \\
\text { costs }\end{array}$ & 3705958,76 & 3506062,31 & $-199896,45$ \\
\hline
\end{tabular}

Table 4. Relative change in GTU costs after LECC introduction

\begin{tabular}{|l|l|l|l|}
\hline Costs & $\begin{array}{l}\text { GTU, } \\
\text { thousand } \\
\text { rubles. }\end{array}$ & $\begin{array}{l}\text { GTU with } \\
\text { LECC, } \\
\text { thousand } \\
\text { rubles. }\end{array}$ & $\begin{array}{l}\text { Relative } \\
\text { deviation, } \\
\text { thousand } \\
\text { rubles }\end{array}$ \\
\hline $\begin{array}{l}\text { Capital } \\
\text { costs }\end{array}$ & 367407,69 & 239391,86 & $-34,84$ \\
\hline $\begin{array}{l}\text { Operational } \\
\text { costs }\end{array}$ & 3705958,76 & 3506062,31 & $-5,39$ \\
\hline
\end{tabular}

According to Tables 3 and 4, it can be concluded that capital costs will decrease by 128,015. 83 thousand rubles, or by $34.84 \%$, and operational costs will be reduced by $199,896.45$ thousand rubles or by $5.39 \%$.

Thus, after introducing LECC at GTU, both capital and operational costs are reduced, which can be considered effective from the point of view of the economic approach.

As for the ratio of capital and operational costs, comparative analysis of the new structure of total costs for the GTU operation showed that after the introduction of LECC, the largest share in the total costs is still occupied by operational costs, accounting for $93.61 \%$ of the total volume, and, capital costs is only $6.39 \%$. The updated cost structure for GTU with LECC is shown in Figure 2.

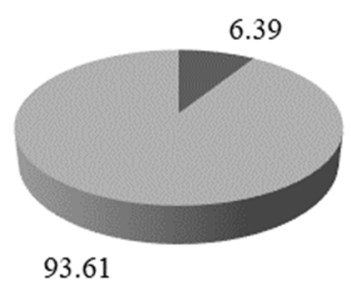

\section{- fixed assets for reconstruction - operational cost}

Figure 2. Cost structure for GTU with LECC, \%

The second stage of the analysis of the innovative product effectiveness- LECC-was the analysis of the consumer value of LECC [18].

According to the approach adopted in this study, the consumer value of the implemented LECC technology, defined as the difference between its utility, value in consumption and the costs of its development and acquisition, is the higher the greater success is achieved in managing the cost price items for its creation.

However, the calculations showed that the actual cost price of LECC does not allow implementing this event at the moment. The difference between the current and planned cost of LECC is shown in Table 5.

Table 5. Difference between the real and planned cost price of LECC, thousand rubles.

\begin{tabular}{|c|c|c|}
\hline $\begin{array}{c}\text { Planned cost } \\
\text { price of LECC }\end{array}$ & $\begin{array}{c}\text { Real cost price } \\
\text { of LECC }\end{array}$ & $\begin{array}{c}\text { Excess of } \\
\text { cost price }\end{array}$ \\
\hline 20087,76 & 73798,99 & 53711,24 \\
\hline
\end{tabular}

At the same time, the planned cost price is understood as the cost price of the LECC, which will allow it to successfully compete with the currently used CC. According to the expert assessment of the specialists of JSC "UEC-Aviadvigatel", the cost increase of using LECC should not exceed $30 \%$ of the cost price of the serial CC; otherwise implementation does not have any pronounced economic effect.

At the same time, as can be seen from Table 5, in order to optimize the cost of GTU by implementing the new LECC technology, it is first necessary to reduce its current cost by 53,711,24 thousand rubles.

This problem is caused by strong overestimation of a number of cost items when calculating the cost of manufacturing LECC. Figure 3 shows the main cost items of the current cost price of LECC.

Figure 3 shows that the main materials and purchased components occupy more than half of the cost price structure $(54.44 \%)$, followed by general production costs $(17.12 \%)$ and basic wages (13.48\%). The lowest share in the total cost structure is taken by additional wages $(2.88 \%)$ and insurance premiums (4.94\%). 


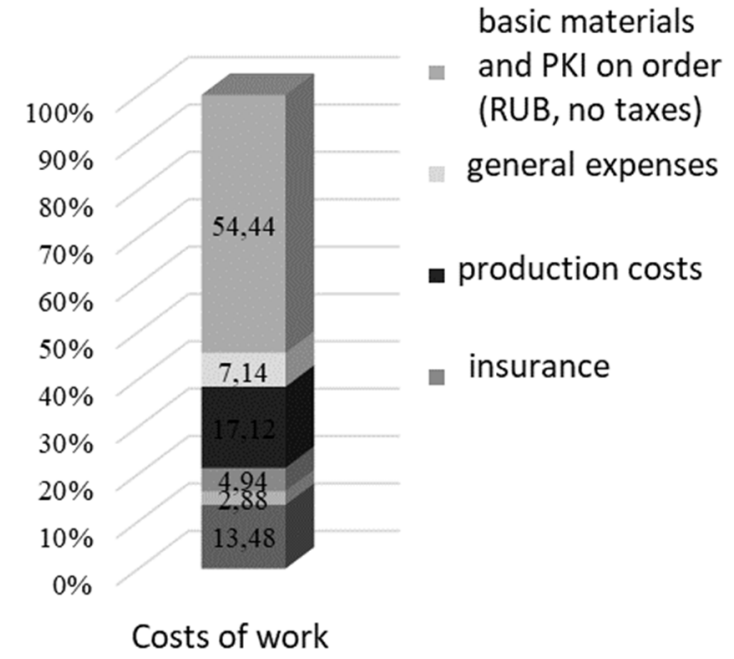

Figure 3. Composition and structure of costs in the cost of LECC, \%

Measures to reduce the cost of LECC should be based primarily on such an element of costs as material costs, since their share in the total cost is the largest and amounts to $54.44 \%$.

Therefore, the main task of the design department of JSC "UEC-Aviadvigatel" is further technological developments for the production of LECC from the point of view of managing individual cost items. At the same time, cost management focuses on reducing or eliminating waste, reducing the cost of materials used, effective pricing, and strategic efficiency improvements.

\section{Conclusion}

Recently, companies have been actively adopting new business models based on changes that allow them to compete in environmental and / or sustainable market segments. As a result, there is a dynamic growth in the importance and popularity of clusters both as a business model used for organizing economic activities and as an instrument of state economic policy.

This study was devoted to analyzing the possibility of widespread introduction of an innovative product in the oil and gas industry - a low-emission combustion chamber (LECC). The introduction of LECC into the GTU structure plays an important role in the development of enterprises in the sector, and can also have a strong impact on the competitiveness of the company that produces it - JSC UEC-Aviadvigatel.

Firstly, the use of LECC reduces the cost of the GTU life cycle. This is of great importance in the competition for the consumer by increasing the consumer value of the product.

Secondly, this development is innovative and allows us to significantly improve the performance, including in the environmental sphere, which is a significant factor for industrial enterprises today.

All the facilities of PJSC Gazprom are planned to be equipped with a low-emission combustion chamber (LECC) produced by UEC-Aviadvigatel [19], which will significantly reduce the harmful load on the atmosphere. Within ten years, it is planned to supply all the facilities of PJSC Gazprom with new equipment.

Thirdly, a significant number of enterprises are considering the possibility of introducing ecoinnovations to simultaneously create economic and environmental value, which is achieved through the use of LECC.

Management technology for the development and creation of LECC is important from the point of view of interaction and exchange of experience within the cluster with other enterprises (foreign and domestic). It also plays an important role in the environmental impact by reducing the negative impact on the environment. It improves the technical and economic usage parameters through application of innovative technologies. However, it has a high cost of creation. Therefore, the issue of reducing the cost price of LECC is important for further development and possible research within the project.

\section{References}

1. R. Baneliene, B. Melnikas, R.Strazdas, E Tolocka. Terra Economicus 16(4) (2018)

2. J. Nkeobuna, N. Ugoani International Journal of Business, Economics and Management 6(4), 232247 (2019)

3. N. Akatov, Zh. Mingaleva, I. Klackova, G. Galieva, N. Shaidurova Management Systems in Production Engineering 27(4), 250-254 (2019).

4. L. E. Valdez-Juárez, M.Castillo-Vergara Journal of Open Innovation: Technology, Market, and Complexity, MDPI, Open Access Journal 7(1), 119 (2020)

5. A.V. Timiryasova, L.N. Safiullin, T.V. Kramin, R.A. Grigoriev Mediterranean Journal of Social Sciences 6(1S3) 96-100 (2015)

6. P.-Y. Nie, C. Wang, L.-K. Lin Area 52(4) 731-740 (2020)

7. M. M. Ospanov, A. T. Uskelenova, K.Kh. Shadiyev Industrial Engineering \& Management Systems 19(1), 59-69 (2020)

8. M.A. Sellitto, C.G. Camfield, S. Buzuku Sustainable Production and Consumption 23, 94104 (2020)

9. Zh. Mingaleva, N. Shaidurova, V. Prajová Management Systems in Production Engineering 26(4), 241-245 (2018).

10. T. Rayna, L. Striukova International Journal of Entrepreneurship and Innovation Management 19(5-6), 285-288 (2015)

11. X. Chen, E. Wang, C. Miao, L. Ji, S.Pan Sustainability 12(7), 2848 (2020)

12. C. Mo, C. He, L. Yang Economics Letters 188, 109003 (2020)

13. A.M. Kowalski, M.Mackiewicz J. Open Innov. Technol. Mark. Complex 7(1), 21 (2021)

14. Zh. Mingaleva, I. Mirskikh Procedia Social and Behavioral Sciences 81 329-333 (2013). 
15. Portal of industrial cooperation of the Perm region Retrieved from: https://prompermkrai.ru/catalog/mashinostroenie/ informatsiya-o-predpriyatii-ne-zapolnena-14-022019-08-47-36

16. A. G. Ishkov, V. G. Nikitin, R. S. Kashapov, A. O. Prokopets, A. N. Poychelyuzny Gasovaya Promyshlennost 750(1) 92-97 (2017).

17. T. Barnes, S. Raynor, J. Bacchus Journal of Strategy and Management 5 (1), 81-102 (2012)

18. S. Chakrabarty Journal of Strategy and Management 13(4), 535-550 (2020)

19. Kommersant Retrieved from: www.kommersant.ru/doc/4112646 